\title{
The win/profit maximization debate: Strategic adaptation as the answer?
}

\author{
Mickael Terrien ${ }^{1}$, Nicolas Scelles ${ }^{2}$, Stephen Morrow ${ }^{2}$, Lionel Maltese ${ }^{3,4}$ and Christophe Durand ${ }^{1}$ \\ ${ }^{1}$ University of Caen Normandy, France \\ ${ }^{2}$ University of Stirling, UK \\ ${ }^{3}$ University Aix-Marseille, France \\ ${ }^{4}$ Kedge Business School, France
}

Accepted for publication in Sport, Business and Management, published by Emerald.

\section{Abstract}

Purpose - The purpose of this paper is twofold. First, to highlight the heterogeneity of the organizational aims within the professional football teams in Ligue 1. Second, to understand why some teams swing from a win orientation toward a soft budget constraint from year to year, and vice versa.

Design/methodology/approach - Financial data from annual reports for the period 2005/06 2014/15 was collected for the 35 Ligue 1 clubs. To define the compliance degree of the intended strategy of those clubs, an efficiency analysis was conducted thanks to the data envelopment analysis (DEA) method. This performance measure was supplemented with the identification of productivity and demand shocks to build a theoretical model. It allow to precise nature of the evolution of the win/profit tension in the utility function related to the gap expectation/performance.

Findings - The paper suggests that a team can switch from one archetype to another from year to year due to the stochastic nature of the sport industry. The club director's utility function could also be maximized under an intertemporal budget function to adjust the weight between win and profit according to the opportunities in the environment.

Originality/value - The paper shed new light on the win/profit maximization. The theoretical model provides an assessment of the weight between win and profit in Ligue 1 and then points a new explanation for persistent losses in the sport industry.

Keywords - Profit maximization, Utility maximization, Football finance, Strategy

Paper type - Research paper 


\section{Introduction}

The economic theory of professional sports leagues is mainly based on the assumption that club owners' objectives are oriented towards either maximizing profits or maximizing utility, more specifically sporting success or wins (Sloane, 2015). The notion of utility maximization can be further divided to reflect the nature of any attendant budget constraint which may be a hard constraint (Sloane, 2015) or a softer one in which club owners do not rigidly enforce the constraint, preferring as necessary to enhance the remuneration of its playing talent in pursuit of winning more games (Andreff, 2007).

Fort (2015) states that estimating the potential trade-off between win and profit maximization is an important avenue for sports economics. This debate, dealing with the aims of professional teams, is crucial as its assumptions impact predictions as to the likely effects of regulatory tools used to optimize the design of leagues (e.g. Szymanski and Késenne, 2004). While some studies have sought to combine the two objectives (for a review, see Fort, 2015), few attempts have been made to clearly understand the organizational objectives of professional team sports (Leach and Szymanski, 2015). One explanation may be that previous approaches have been too strongly focused on economic background while managerial concepts may help to clarify such organizational objectives. More specifically, whereas an economic approach tends to assume that intended strategy will be realized (e.g. Sloane, 1971), recognition that "strategies can 'form' in a variety of different ways" (Mintzberg et Waters, 1985, p.160) is potentially of great importance in professional team sports. Hence, the resultant trade-off between profit and win could be the consequence of strategy formulation or may result from a potential misalignment in its implementation.

In order to enhance the existing literature, this paper analyzes French football clubs in the first division, called Ligue 1, between 2005/06 and 2014/15. Basic financial analysis illustrates the heterogeneity of organizational aims among Ligue 1 clubs: one third of clubs makes significant profits, another third achieve a break-even position, whereas the final third incur substantial losses. Over the period, it is common to see a club switching from one orientation to another. Based on this observation, a theoretical model is built to understand the instability of club owners' objectives. Based upon a dialectical analysis of the relation between the means used and the results achieved (Avenier, 1999), the model enables a distinction to be drawn between an unrealized strategy and a decision to adapt organizational objectives in cognizance of an emerging opportunity. The efficiency scores measured using data envelopment analysis (DEA) and the presence of productivity and demand shocks (Szymanski, 2012) can reveal the strategic intent of club owners. Data shows that some French football teams seem to maximize their utility under an inter-temporal budget constraint. In order to seize opportunities and to minimize environmental risks, those clubs may alter from win orientation towards profit maximization from year to year, and vice versa.

This remainder of the paper is organized as follows. First, the win/profit maximization debate is considered. Second, financial data is used to identify the most relevant assumptions in respect of the organizational objectives of French football teams. In the third section, the degree of compliance with the intended strategy is assessed to control for the possibility that the outcomes may be unexpected. In the fourth section, a theoretical model is built to understand why a football team may switch from profit to win maximization (and vice versa) from year to year. Thereafter, the findings of the research are presented and highlighted drawing on a number of detailed examples, followed by a discussion of the results. The model enables us to reconcile different theories concerned with 
persistent loss making in the football industry and to offer a new explanation in respect of financial performance. The implications of heterogeneity in club owners' behaviour are also considered.

\section{The win/profit maximization debate}

Rottenberg (1956) provided the first modeling of a sport team production function. He assumed that Major League Baseball franchises were, like 'classic firms', oriented toward profit maximization. In contrast, based on the recurring deficits of English football clubs, Sloane (1971) claimed that European club owners were prioritizing utility maximization, with clubs concerned with multiple objectives, which include wins and profit, but may also include attendance objectives and the financial health of the league. As the strategic interactions of European football teams within a league are assumed to be non-cooperative (Szymanski and Késenne, 2004), the latter objective could be viewed as secondary. The attendance objective is sometimes used as a proxy for social aspects of organizational performance when the latter is empirically assessed (e.g. Kern, Schwarzmann and Wiedenegger, 2012). However, social performance cannot be captured by a single indicator such as stadium utilization given its multi-faceted nature, and hence consideration is required of other aspects of clubs' performance, such as the effectiveness of its corporate social responsibility programmes (see, for example, Anagnostopoulos \& Kolyperas, 2015; Bason \& Anagnostopoulos, 2015; Breitbarth et al., 2015).

Aside from a small number of analytical studies (see for example, Madden and Robinson, 2012), the club owners' utility function does not take account of social dimension of performance and has tended to be interpreted as win maximization under some form of budget constraint (Fort, 2015), generally a strict or hard constraint $(\pi=0$, e.g. Késenne, 1996). However, as has been well documented, despite rising revenues for a number of years European football has reported declining financial performance and position, with many clubs in perilous financial circumstances clubs (Morrow, 2014a; Storm and Nielsen, 2012). For example, in 2011, 63\% of European football clubs reported losses (UEFA, 2013).

In this context therefore, the utility function may be interpreted as the pursuit of sporting success subject to an acceptable level of financial losses (for an analytical application, see Terrien, Scelles and Durand 2016). This assumption of a soft budget constraint was pioneered by Kornaï (1980) in the context of behaviour in socialist economies where organizations such as state enterprises, banks or professional football teams, knowing that they will be rescued if they sustain losses may ex ante alter their behavior (Andreff, 2007; Storm, 2012; Storm and Nielsen, 2012). This issue in the agency relationship has been well observed in European football, where it is common practice to see the shareholders (DNCG, 2015), a bank (Ascari and Gagnepain, 2006) or the local authorities (Baroncelli and Lago, 2006) becoming funders of last resort.

To sum up, if we focus on the trade-off between profit and win while leaving aside the social dimension, three objectives of professional sports teams are found in the literature:

- Profit maximization under sporting constraint (I);

- Win maximization under hard budget constraint (II);

- Win maximization under soft budget constraint (III). 
The main strategic option is between profit and win maximization, whereas the nature of the budget constraint may depend on environmental conditions, specifically: the social importance of the team (Storm and Nielsen, 2012), the governance mechanisms within the organization, the league (Andreff, 2007) or the international federation (to access to the European competitions, Franck, 2016).

It is commonplace to assume that North American teams optimize their production to get $I$, whereas European teams are looking for win maximization, even if the nature of the budget constraint is a subject of debate (II or III). The difference between the two continents is explained by the degree of competition in each league (Szymanski and Zimbalist, 2005). The open league system in Europe (the promotion-relegation mechanism) provides a higher degree of competition and risk which encourages teams to invest in talent as much as they can. This lead to a non-cooperative Nash equilibrium (Szymanski and Késenne, 2004), where teams enter a rat race (Andreff, 2016), the objective of which may be, for example, to avoid relegation, to qualify for European competitions or to become champions.

These two basic premises are of central interest in the regulation of professional sport leagues. Indeed, the invariance principle introduced by Rottenberg (1956) states that many regulatory interventions such as gate revenue sharing or the draft system in fact have no effect on the first objective - competitive balance - when teams are oriented toward profit maximization, a principle subsequently confirmed by other authors (Quirk and El Hodiri, 1974; Vrooman, 1997). Nevertheless, when club owners' utility function is assumed to favour wins at the expense of profit, the invariance principle no longer holds (Szymanski and Késenne, 2004). Therefore an external regulation could be useful to optimize the attractiveness of a professional league (Terrien et al., 2016).

One exception must be highlighted to these basic premises, namely the suggestion that European clubs that acquired a stock exchange listing are assumed to be profit oriented (Andreff, 2014). Wilson, Plumley and Ramchandani (2013) claim that English football clubs which have floated on the stock exchange report improved financial health. However, Leach and Szymanski $(2015$, p.25) find no evidence of any alteration in the behaviour or performance of listed clubs post flotation, noting that (English) football clubs are "more oriented toward profit objectives than [...] normally assumed". Whether clubs oriented toward profit choose to float on a stock exchange or not, this exception is important as it introduces heterogeneity of objectives between clubs within a league. Taking into account this diversity is a major issue as it has potential implications for policy measures (Rascher, 1997; Terrien et al., 2016).

Notwithstanding a considerable volume of empirical and theoretical studies that are concerned with the debate between profit and win maximization, according to Leach and Szymanski (2015, pp. 2526) the "literature neither offers a firm conclusion nor clearly establishes evidence supporting one hypothesis over the other". One explanation could come from the coexistence of those objectives both within a league and within a given club over a given time period.

\section{Financial analysis: Ligue 1 from 2005/06 to 2014/15}

Different accounting indicators can be used to measure the financial performance of professional football clubs (Plumley, Wilson and Ramchandani, 2014) with regard to the the trade-off between profit and win. As the focus of this paper is on the profit and utility maximization objectives of clubs, 
our analysis concentrates on clubs' relative operating profit, i.e. operating profit related to operating revenue. This ratio is used to operationalize the three objectives of European football clubs described in the previous section. This accounting ratio is considered preferable to the net financial result since the latter can be distorted due to exceptional income or expenditure. For example, over the period 2006/07 - 2011/12, Rennes registered a nil profit every year, yet its operating profit / (loss) varied between $(€ 10,9 \mathrm{M})$ and $€ 13,6 \mathrm{M}$, as a result of exceptional items. This financial data, along with other financial data used to derive the theoretical model, is drawn from the annual reports published annually by the Direction Nationale du Contrôle de Gestion (DNCG; National Direction for Management Control). ${ }^{[i]}$

Table 1 provides the three objectives related to the profit/utility debate and their operationalization. According to Storm and Nielsen (2012, p. 187), "perfect softness' is a state of affairs where differences between proceeds from sales and costs from production are not a matter of life and death (Kornai, 1980b, p. 308)". As the concept of actual losses appears to be central, we operationalize the soft budget constraint using a negative threshold for the relative operating profit. Financial Fair Play defines the 'acceptable deviation' from the break-even requirement at $€ 5 \mathrm{M}$ (Franck, 2016). As the size of club budgets in Ligue 1 are markedly different (e.g. from $€ 25 \mathrm{M}$ for Lens to €480M for Paris Saint-Germain in 2014/15), a relative measure is considered to provide a better operationalization.

Table 1 - The generic strategies of professional sport clubs

\begin{tabular}{|c|c|c|}
\hline \multicolumn{2}{|c|}{ Objectives } & Operationalization \\
\hline \multicolumn{2}{|c|}{ Profit maximization under sporting constraint (I) } & Relative operating profit is greater than $5 \%$ \\
\hline $\begin{array}{c}\text { Win maximization } \\
\text { under }\end{array}$ & Hard budget constraint (II) & $\begin{array}{c}\text { Relative operating profit / (loss) is between } \\
(5 \%) \text { and } 5 \%\end{array}$ \\
\cline { 2 - 3 } & Soft budget constraint (III) & Relative operating loss is greater than $5 \%$ \\
\hline
\end{tabular}

Table 2 sheds light on the coexistence of the three objectives for French clubs which participated in Ligue 1 over the period 2005/06 - 2014/15 (200 observations).

Table 2 - Heterogeneity in the objectives of the French football clubs (overview)

\begin{tabular}{|c|c|c|c|c|c|c|c|c|c|c|c|c|}
\hline \multicolumn{2}{|c|}{$\begin{array}{c}\text { Relative } \\
\text { operating profit }\end{array}$} & $\begin{array}{l}2005 \\
/ 06\end{array}$ & $\begin{array}{c}2006 \\
/ 07\end{array}$ & $\begin{array}{c}2007 \\
/ 08\end{array}$ & $\begin{array}{c}2008 \\
/ 09\end{array}$ & $\begin{array}{c}2009 \\
/ 10\end{array}$ & $\begin{array}{c}2010 \\
/ 11\end{array}$ & $\begin{array}{c}2011 \\
/ 12\end{array}$ & $\begin{array}{c}2012 \\
/ 13\end{array}$ & $\begin{array}{c}2013 \\
/ 14\end{array}$ & $\begin{array}{c}2014 \\
/ 15\end{array}$ & Total (\%) \\
\hline \multirow{3}{*}{$\begin{array}{l}\text { Number } \\
\text { of teams }\end{array}$} & $I$ & 11 & 13 & 10 & 3 & 4 & 9 & 5 & 7 & 4 & 3 & 69 (34.5\%) \\
\hline & II & 6 & 3 & 7 & 12 & 4 & 3 & 8 & 7 & 5 & 8 & $63(31.5 \%)$ \\
\hline & III & 3 & 4 & 3 & 5 & 12 & 8 & 7 & 6 & 11 & 9 & $68(34 \%)$ \\
\hline
\end{tabular}

What is clear is the heterogeneity in relative operating profits among French clubs. The financial analysis provides some support for Leach and Szymanski (2015)'s claim that European leagues are more profit oriented than is normally assumed, with clubs being quite evenly dispersed among the three categories.

Based on this static analysis, one may argue that some clubs are looking for profit whereas others try to maximize sporting outcomes under hard or soft budget constraints. Ostensibly one interpretation is that annual changes in Table 2 arise from the introduction of new clubs (three promotions and relegations every season) and/or changes in ownership, with the utility functions of owners assumed to be stable from year to year. However, more detailed analysis suggests that in fact it is common 
practice for clubs to alter their objectives from year to year. Table 3 highlights this phenomenon for clubs which have spent at least four seasons in Ligue 1 over the time period of analysis.

Table 3 - Heterogeneity in the objectives of the French football clubs, club by club

\begin{tabular}{|c|c|c|c|c|}
\hline \multirow{2}{*}{ Teams } & \multicolumn{4}{|c|}{ Number of seasons from 2005/06 to 2014/15 } \\
\cline { 2 - 5 } & \multicolumn{2}{|c|}{ In category: } & \multirow{2}{*}{ Total in Ligue 1 } \\
\cline { 2 - 5 } & $I$ & II & III & \\
\hline AC Ajaccio & 2 & 0 & 2 & 4 \\
\hline AJ Auxerre & 2 & 2 & 3 & 7 \\
\hline AS Monaco & 0 & 1 & 7 & 8 \\
\hline AS Nancy Lorraine & 3 & 3 & 2 & 8 \\
\hline AS Saint-Etienne & 5 & 4 & 1 & 10 \\
\hline Evian TG FC & 0 & 3 & 1 & 4 \\
\hline FC Girondins de Bordeaux & 4 & 1 & 5 & 10 \\
\hline FC Lorient & 5 & 2 & 2 & 9 \\
\hline FC Nantes & 2 & 0 & 3 & 5 \\
\hline FC Sochaux Montbéliard & 5 & 2 & 2 & 9 \\
\hline Le Mans UC 72 & 2 & 2 & 1 & 5 \\
\hline LOSC Lille Métropole & 5 & 3 & 2 & 10 \\
\hline Montpellier Hérault SC & 5 & 0 & 1 & 6 \\
\hline OGC Nice & 5 & 2 & 3 & 10 \\
\hline Olympique de Marseille & 3 & 2 & 5 & 10 \\
\hline Olympique Lyonnais & 3 & 1 & 6 & 10 \\
\hline Paris Saint-Germain & 0 & 5 & 5 & 10 \\
\hline Racing Club de Lens & 3 & 1 & 2 & 6 \\
\hline SM Caen & 0 & 4 & 1 & 5 \\
\hline Stade Rennais FC & 4 & 2 & 4 & 10 \\
\hline Toulouse FC & 2 & 7 & 1 & 10 \\
\hline Valenciennes FC & 0 & 3 & 5 & 8 \\
\hline
\end{tabular}

These variations can be explained by the instability of the weights in the trade-off between profit and win, or by exogenous factors preventing the achievement of the initial objective for a club. Central to the differentiation between the sport industry and more conventional areas of business activity is the uncertainty of sporting competition and the consequences arising therefrom. Notwithstanding the causality between payroll and sporting outcome (Hall, Szymanski and Zimbalist, 2002), there could still be a difference in sporting performance of 20 points in Ligue 1 between two teams with an equal payroll, regardless of the size of that payroll (DNCG, 2015, p. 51). As sporting productivity impacts clubs' income (Szymanski, 2012), inevitably financial outcome is inherently uncertain. Since the spending level is primarily determined at the beginning of the season, the relative operating profit may be higher (lower) than expected if there is a sporting over (under) performance. Similarly, unexpected incomes or income lower than expected during the season may explain the swing of French clubs from one objective to another. 
Mintzberg, Ahlstand and Shamsie (1998) provide a useful distinction between intended and realized strategy to highlight this phenomenon. They argue that intent may be unrealized if the expected outcome is not achieved and/or the deliberate strategy is adapted to an emerging opportunity. In the first case, sporting uncertainty may explain deviation from the initial objective. Under the latter, the new objective might reflect a realignment of strategy in cognizance of environmental change.

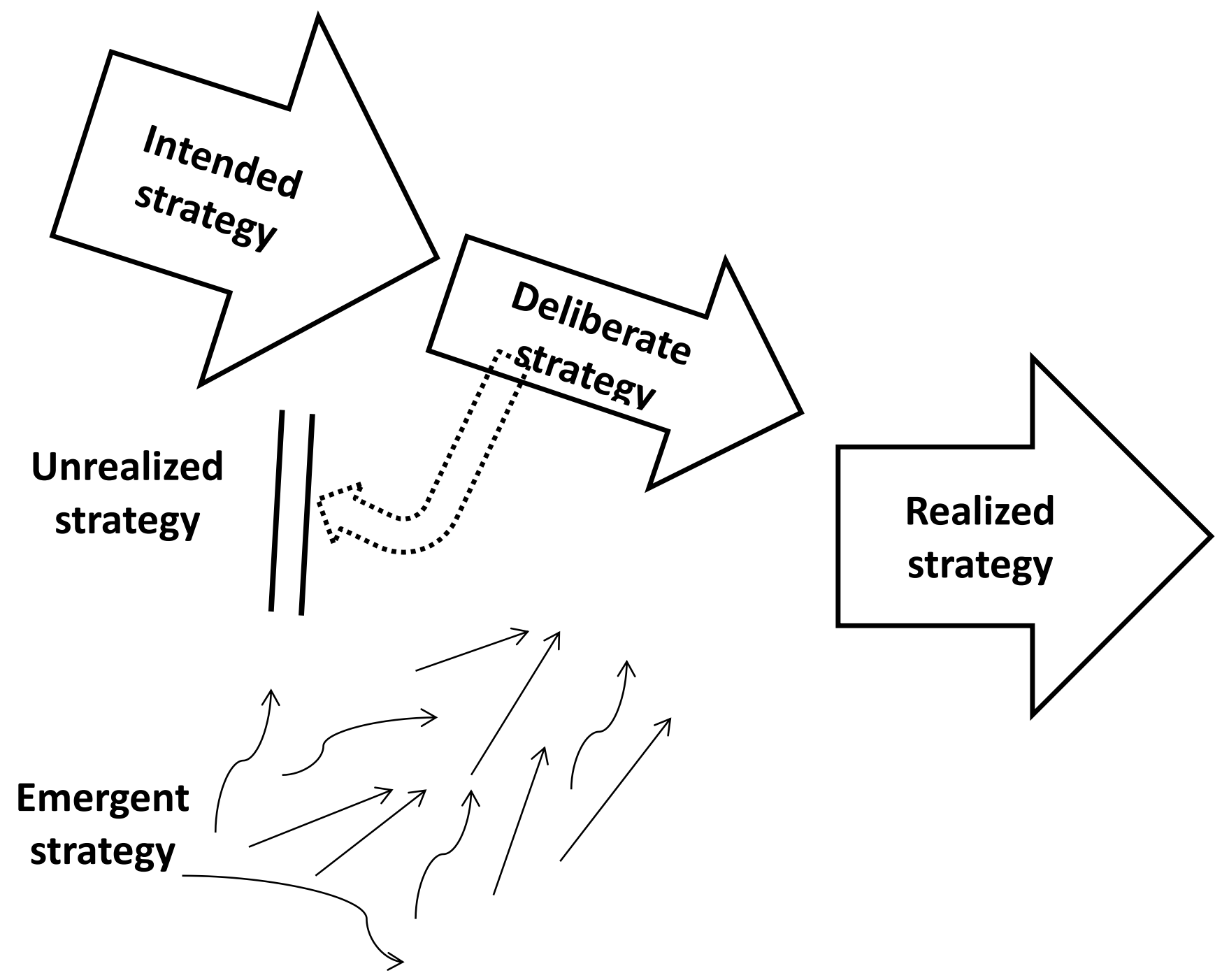

Figure 1 - The different types of strategies (Mintzberg et al., 1998, p.12)

In order to understand the trade-off between win and profit maximization, it is necessary therefore to control for the degree of compliance with the intended strategy and not rely solely on the relative operating profit. Hence, significant financial losses (profits) do not necessarily reflect an orientation toward a win maximization objective (profit maximization objective).

\section{The degree of compliance with the intended strategy}

To get an idea of the degree of compliance with the strategic intent, it is necessary to identify the realized strategy and identify an indicator which enables us to measure whether organizational performance was maximal or not. DEA analysis, which has been applied many times in the sport industry (e.g. Guzman and Morrow, 2007; Kern et al., 2012), is introduced to measure the pure 
managerial efficiency of French football teams. This non-parametric method follows the microeconomic reasoning of an optimizer producer and treats each decision making unit (DMU) as a "black box" by considering only the inputs consumed and the outputs produced. Therefore, it enables a multi-output evaluation without taking any assumption dealing with the weight of each output.

Two inputs (payroll and other expenses) and two outputs (points in Ligue 1 and operational revenue) are selected to draw the efficiency frontier. Those four variables are commonly used in the literature dealing with the efficiency of professional sports teams (e.g. Barros and Garcia-del-Barrio, 2011). Any observation located on the frontier is efficient (efficiency score equal to one), whereas the others are not (efficiency below one). As the efficiency scores of the 200 observations ( 20 teams over 10 seasons) do not follow a normal distribution, the only distinction retained is the difference between maximal and non-maximal scores, regardless of the exact value for the latter.

To complete the organizational performance evaluation, the theoretical model includes the identification of productivity and demand shocks (Leach, 2007; Szymanski, 2012). This enables measurement of the gap between the actual sporting and financial performances and what the club might have expected at the beginning of the season (Lassalle, Meschi and Métais, 2012). Specifically, the shocks are the differences between the actual and predicted performance, i.e. the residuals. Therefore, two ordinary least squares regressions are run in order to identify those residuals.

First, the productivity shocks are identified using the following equation:

$$
\begin{aligned}
\Delta \ln p_{i, t}=\beta_{0}+ & \beta_{1} \ln _{i, t-1}+\beta_{2} \Delta \ln p_{i, t-1}+\beta_{3} \ln r e l w_{i, t-1}+\beta_{4} \Delta \ln r e l w_{i, t} \\
& + \text { promotion dummies }+\varepsilon_{i, t}
\end{aligned}
$$

where $\ln p_{i, t}$ is the log odds position (-In (P/(44-P)) of team $i$ during season $t$, with 44 being the worst ranking in $t-2$ ( $3^{\text {rd }}$ of the National championship) plus one. rel $w$ is the club wage bill divided by the sum of the wage bills for all clubs in that season. The model controls for fixed effects and therefore, only the teams which have spent four years in Ligue 1 are taken into account ( $N=174$ observations, 22 clubs).

Second, the demand shocks are derived from the following equation:

$$
\begin{aligned}
\Delta \operatorname{relrev} v_{i, t}= & \gamma_{0}+\gamma_{1} \ln r e l r e v_{i, t-1}+\gamma_{2} \Delta \ln r e l \operatorname{rev}_{i, t-1}+\gamma_{3} p_{i, t}+\gamma_{4} \Delta \ln p_{i, t} \\
& + \text { promotion dummies }+\eta_{i, t}
\end{aligned}
$$

where rel rev is the total turnover of a club taken from the annual report and divided by the sum of the turnovers of all clubs in that season.

Tables 4 and 5 provide the results for the regressions (1) and (2). 
Table 4 - Performance regressions in Ligue 1 over the period 2005/06 - 2014/15

\begin{tabular}{|c|c|c|c|c|c|}
\hline$\Delta \ln p_{i, t}$ & $\begin{array}{c}\text { All } \\
\text { observations }\end{array}$ & \begin{tabular}{l}
\multicolumn{1}{c}{ All } \\
observations \\
(without the \\
promotions \\
dummies)
\end{tabular} & $\begin{array}{l}\text { All observations } \\
\text { (without the } \\
\text { promotions } \\
\text { dummies) with } \\
\text { fixed effects }\end{array}$ & $\begin{array}{l}\text { At least four } \\
\text { seasons in } \\
\text { Ligue } 1 \\
\text { (without the } \\
\text { promotions } \\
\text { dummies) }\end{array}$ & $\begin{array}{l}\text { At least four } \\
\text { seasons in Ligue } \\
1 \text { (without the } \\
\text { promotions } \\
\text { dummies) with } \\
\text { fixed effects }\end{array}$ \\
\hline $\ln p_{i, t-1}$ & $\begin{array}{c}0.343 * * * \\
(0.098)\end{array}$ & $\begin{array}{c}0.324 * * * \\
0.074\end{array}$ & $\begin{array}{l}-0.136 * \\
(0.080)\end{array}$ & $\begin{array}{c}0.293 * * * \\
(0.085)\end{array}$ & $\begin{array}{l}-0.152 * \\
(0.087)\end{array}$ \\
\hline$\Delta \ln p_{i, t-1}$ & $\begin{array}{c}-0.173 * * * \\
(0.060)\end{array}$ & $\begin{array}{c}-0.164 * * * \\
(0.054)\end{array}$ & $\begin{array}{c}0.003 \\
(0.060)\end{array}$ & $\begin{array}{c}-0.162^{* *} \\
(0.067)\end{array}$ & $\begin{array}{c}0.012 \\
(0.066)\end{array}$ \\
\hline $\ln r e l w_{i, t}$ & $\begin{array}{c}11.726 * * * \\
(3.000)\end{array}$ & $\begin{array}{c}11.981^{* * *} \\
(2.814)\end{array}$ & $\begin{array}{c}16.353 * * * \\
(2.767)\end{array}$ & $\begin{array}{c}11.998 * * * \\
(2.869)\end{array}$ & $\begin{array}{c}16.566^{* * *} \\
(2.754)\end{array}$ \\
\hline$\Delta \ln r e l w_{i, t-1}$ & $\begin{array}{c}28.814^{* * *} \\
(8.143)\end{array}$ & $\begin{array}{c}29.115^{* * *} \\
(7.953)\end{array}$ & $\begin{array}{c}33.743 * * * \\
(6.277)\end{array}$ & $\begin{array}{c}28.874 * * * \\
(7.876)\end{array}$ & $\begin{array}{c}33.923 * * * \\
(6.179)\end{array}$ \\
\hline $\begin{array}{l}\text { Promotion } \\
\text { dummies }\end{array}$ & $\begin{array}{c}0.062 \\
(0.164)\end{array}$ & - & - & - & - \\
\hline Constant & $\begin{array}{c}0.434 * * * \\
0.099\end{array}$ & $\begin{array}{c}0.456 * * * \\
(0.077)\end{array}$ & $\begin{array}{l}-0.067 \\
(0.049)\end{array}$ & $\begin{array}{c}0.529 * * * \\
(0.089)\end{array}$ & $\begin{array}{c}0.530 * * * \\
(0.128)\end{array}$ \\
\hline Observations & 200 & 200 & 200 & 174 & 174 \\
\hline $\begin{array}{c}\text { Number of } \\
\text { teams }\end{array}$ & 35 & 35 & 35 & 22 & 22 \\
\hline $\mathrm{R}^{2}$ & 0.579 & 0.578 & 0.719 & 0.538 & 0.678 \\
\hline
\end{tabular}

$*, * *$ and $* * *$ mean respectively significant at the 10,5 and $1 \%$ levels. Robust standard errors in brackets.

Table 5 - Demand regressions in Ligue 1 over the period 2005/06 - 2014/15

\begin{tabular}{|c|c|c|c|c|c|}
\hline$\Delta \ln r e l r e v_{i, t}$ & $\begin{array}{c}\text { All } \\
\text { observations }\end{array}$ & $\begin{array}{c}\text { All observations } \\
\text { (without } \\
\Delta \ln \operatorname{rel~rev}_{i, t-1)} \text { ) }\end{array}$ & $\begin{array}{l}\text { All observations } \\
\text { (without } \\
\text { Lln rel rev } v_{i, t-1} \\
\text { ) with fixed } \\
\text { effects }\end{array}$ & $\begin{array}{c}\text { At least four } \\
\text { seasons in Ligue } \\
1 \text { (without } \\
\text { dn rel rev } \operatorname{rev}_{i, t-1} \\
\text { ) }\end{array}$ & $\begin{array}{l}\text { At least four } \\
\text { seasons in } \\
\text { Ligue } 1 \\
\text { (without } \\
\Delta \ln \text { rel rev } \boldsymbol{y}_{i, t-1} \\
\text { ) with fixed } \\
\text { effects }\end{array}$ \\
\hline $\ln r e l r e v_{i, t-1}$ & $\begin{array}{c}0.902 * * * \\
(0.063)\end{array}$ & $\begin{array}{c}0.938 * * * \\
(0.070)\end{array}$ & $\begin{array}{c}0.733^{* * *} \\
(0.074)\end{array}$ & $\begin{array}{c}0.937 * * * \\
(0.069)\end{array}$ & \begin{tabular}{|c|}
$0.734^{* * *}$ \\
$(0.071)$ \\
\end{tabular} \\
\hline$\Delta \ln$ rel rev $v_{i, t-}$ & $\begin{array}{l}-0.177 \\
(0.180)\end{array}$ & - & - & - & - \\
\hline $\ln p_{i, t-1}$ & $\begin{array}{c}0.007 * * * \\
(0.002)\end{array}$ & $\begin{array}{c}0.007 * * * \\
(0.002)\end{array}$ & $\begin{array}{c}0.019 * * * \\
(0.004)\end{array}$ & $\begin{array}{c}0.008 * * * \\
(0.002)\end{array}$ & $\begin{array}{c}0.019 * * * \\
(0.003)\end{array}$ \\
\hline$\Delta \ln p_{i, t-1}$ & $\begin{array}{c}0.009 * * * \\
(0.002)\end{array}$ & $\begin{array}{c}0.008^{* * *} \\
(0.002)\end{array}$ & $\begin{array}{c}0.013 * * * \\
(0.002)\end{array}$ & $\begin{array}{c}0.009 * * * \\
(0.002)\end{array}$ & $\begin{array}{c}0.013^{* * *} \\
(0.002)\end{array}$ \\
\hline $\begin{array}{l}\text { Promotion } \\
\text { dummies }\end{array}$ & $\begin{array}{c}0.015^{* * *} \\
(0.003)\end{array}$ & $\begin{array}{c}0.015^{* * *} \\
(0.003)\end{array}$ & $\begin{array}{c}0.017^{* * *} \\
(0.003)\end{array}$ & $\begin{array}{c}0.018 * * * \\
(0.004)\end{array}$ & $\begin{array}{c}0.021 * * * \\
(0.005)\end{array}$ \\
\hline Constant & $-0.007 * * *$ & $-0.008 * * *$ & $-0.008 * *$ & $-0.009 * * *$ & $-0.035 * * *$ \\
\hline
\end{tabular}




\begin{tabular}{|c|c|c|c|c|c|} 
& $(0.002)$ & $(0.002)$ & $(0.004)$ & $(0.002)$ & $(0.010)$ \\
\hline Observations & 191 & 200 & 200 & 174 & 174 \\
\hline $\begin{array}{c}\text { Number of } \\
\text { clubs }\end{array}$ & 34 & 35 & 35 & 22 & 22 \\
\hline $\mathrm{R}^{2}$ & 0.892 & 0.889 & 0.925 & 0.885 & 0.922 \\
\hline
\end{tabular}

$*, * *$ and $* * *$ mean respectively significant at the 10,5 and $1 \%$ levels. Robust standard errors in brackets.

The two tables show that the variables promotion dummies in (1) and $\Delta \ln$ rel rev $_{i, t-1}$ in (2) are not significant (column 1), and hence they are removed from the other regressions. The last columns of the two tables are the regressions of interest. These focus on the clubs that spent at least four seasons in Ligue 1, in order to incorporate the fixed effects in the regressions without having too many variables (26 variables for 174 observations here). Those dummies are important to assess team expectations as they capture their sporting and commercial expertise.

A typology may be defined based on the difference between the average (which is almost 0 ) and the standard deviation (Table 6).

Table 6 - Typology of the residuals from (1) and (2)

\begin{tabular}{|c|c|c|c|}
\cline { 2 - 4 } \multicolumn{1}{c|}{} & Negative shock & No shock & Positive shock \\
\hline Productivity & $\varepsilon_{i, t} \leq \bar{x}-\sigma$ & $\left.\varepsilon_{i, t} \in\right] \bar{x}-\sigma ; \bar{x}+\sigma[$ & $\varepsilon_{i, t} \geq \bar{x}+\sigma$ \\
\hline Demand & $\eta_{i, t} \leq \bar{x}-\sigma$ & $\left.\eta_{i, t} \in\right] \bar{x}-\sigma ; \bar{x}+\sigma[$ & $\eta_{i, t} \geq \bar{x}+\sigma$ \\
\hline
\end{tabular}

This classification results in the identification of 24 positive and 28 negative productivity shocks, and 8 positive and 11 negative demand shocks. Based on the relative operating profits, the efficiency scores and the residuals from (1) and (2), it is thus possible to provide a typology analysis of the dialectic relation between ends and means (Avenier, 1999). 18 categories are distinguished and a degree of compliance is defined for each of them (Table 7). When a team achieves a good (bad) performance, the relative operating profit is assumed to be potentially higher (lower) than the initial expectation. This enables us to define if the intended strategy has been realized or not.

Table 7 - Typological analysis of the dialectic relation between ends and means

\begin{tabular}{|c|c|c|c|c|c|c|}
\hline $\begin{array}{c}\text { Relative } \\
\text { operating } \\
\text { profit } \\
\end{array}$ & Efficiency & $\begin{array}{l}\text { Productivity and } \\
\text { demand } \\
\text { shocks }{ }^{[i i]}\end{array}$ & Typology & $\begin{array}{c}\text { Occurrences } \\
\text { (\%) }\end{array}$ & $\begin{array}{l}\text { Intended } \\
\text { strategy }\end{array}$ & $\begin{array}{l}\text { Potential } \\
\text { strategies }\end{array}$ \\
\hline \multirow{6}{*}{$\begin{array}{c}\text { Win } \\
\text { maximization } \\
\text { under soft } \\
\text { budget } \\
\text { constraint } \\
\text { (III) }\end{array}$} & \multirow{3}{*}{$\begin{array}{c}\text { Non } \\
\text { maximal }\end{array}$} & No & 18 & $34(17 \%)$ & Uncertain & II or III \\
\hline & & Negative & 17 & $18(9 \%)$ & Uncertain & I or II or III \\
\hline & & Positive & 16 & $0(0 \%)$ & III & \\
\hline & \multirow{3}{*}{ Maximal } & No & 15 & $12(6 \%)$ & III & \\
\hline & & Negative & 14 & $0(0 \%)$ & III & \\
\hline & & Positive & 13 & $4(2 \%)$ & III & \\
\hline \multirow{3}{*}{$\begin{array}{c}\text { Win } \\
\text { maximization } \\
\text { under hard }\end{array}$} & \multirow{3}{*}{$\begin{array}{c}\text { Non } \\
\text { maximal }\end{array}$} & No & 12 & 31 (15.5\%) & II & \\
\hline & & Negative & 11 & $4(2 \%)$ & Uncertain & I or II \\
\hline & & Positive & 10 & $2(1 \%)$ & Uncertain & II or III \\
\hline
\end{tabular}




\begin{tabular}{|c|c|c|c|c|c|c|}
\hline \multirow{3}{*}{$\begin{array}{l}\text { budget } \\
\text { constraint } \\
\text { (II) }\end{array}$} & \multirow{3}{*}{ Maximal } & No & 9 & $18(9 \%)$ & II & \\
\hline & & Negative & 8 & $2(1 \%)$ & Uncertain & I or II \\
\hline & & Positive & 7 & $6(3 \%)$ & Uncertain & II or III \\
\hline \multirow{6}{*}{$\begin{array}{c}\text { Profit } \\
\text { maximization } \\
\text { under } \\
\text { sporting } \\
\text { constraint } \\
\text { (I) }\end{array}$} & \multirow{3}{*}{$\begin{array}{c}\text { Non } \\
\text { maximal }\end{array}$} & No & 6 & $20(10 \%)$ & 1 & \\
\hline & & Negative & 5 & 7 (3.5\%) & 1 & \\
\hline & & Positive & 4 & $0(0 \%)$ & $\mathrm{I}$ & \\
\hline & \multirow{3}{*}{ Maximal } & No & 3 & 29 (14.5\%) & Uncertain & I or II \\
\hline & & Negative & 2 & $1(0.5 \%)$ & I & \\
\hline & & Positive & 1 & $12(6 \%)$ & Uncertain & I or II or III \\
\hline
\end{tabular}

Mintzberg and Waters (1985, p. 268) stress the challenges faced in operationalizing strategy: "when intentions are sufficiently malleable, everything can seem deliberate." Therefore, the typological analysis tries to be deterministic enough to identify the intended strategy, while enabling the possibility of deviation from the intention.

\section{Theoretical model}

The main focus of interest here is the consistency of strategy over time. According to the transition in the typologies identified in Table 7 between $t$ and $t+1$, the theoretical model defines three configurations (Table 8).

Table 8 - Theoretical model

\begin{tabular}{|c|c|c|c|}
\hline $\begin{array}{c}\text { Intended } \\
\text { strategy }\end{array}$ & Description & \multicolumn{2}{|c|}{ Example } \\
\hline Realized & $\begin{array}{c}\text { The generic strategy in } t+1 \text { is the same } \\
\text { as intended in } t\end{array}$ & $\begin{array}{c}15 \\
\text { to } \\
18\end{array}$ & $\begin{array}{c}\text { The club has maintained the objective } \\
\text { of win maximization under a soft } \\
\text { budget constraint in } t+1 \text { but was not } \\
\text { efficient as in } t\end{array}$ \\
\hline $\begin{array}{c}\text { Involuntarily } \\
\text { non realized }\end{array}$ & $\begin{array}{c}\text { The uncertainty of sport explains the } \\
\text { change in objective between } t \text { et } t+1 \\
\text { (transition foreseen by the model) }\end{array}$ & $\begin{array}{c}12 \\
\text { to } \\
1\end{array}$ & $\begin{array}{c}\text { Sporting over performance (positive } \\
\text { shock in } t+1 \text { ) leads to a profit above } \\
\text { club expectations }\end{array}$ \\
\hline $\begin{array}{c}\text { Voluntarily non } \\
\text { realized }\end{array}$ & $\begin{array}{c}\text { Strategic adaptation explains the } \\
\text { change in objective between } t \text { and } t+1 \\
\text { (transition not expected by the model) }\end{array}$ & $\begin{array}{c}9 \\
\text { to }\end{array}$ & $\begin{array}{c}\text { The club switches from win } \\
\text { maximization under a hard budget } \\
\text { constraint to a soft budget constraint }\end{array}$ \\
\hline
\end{tabular}

144 transitions between two successive seasons in Ligue 1 for the teams which spent at least four seasons in this championship between 2005/06 and 2014/15 are identified. Table 9 provides a mapping of the typologies for those observations. 
Table 9 - Typologies of Ligue 1 French football clubs: 2005/06 to 2014/15

\begin{tabular}{|c|c|c|c|c|c|c|c|c|c|c|}
\hline Clubs & $2005 / 06$ & $2006 / 07$ & $2007 / 08$ & 2008/09 & $2009 / 10$ & 2010/11 & $2011 / 12$ & $2012 / 13$ & $2013 / 14$ & $2014 / 15$ \\
\hline AC Ajaccio & 3 & & & & & & 3 & 15 & 15 & \\
\hline AJ Auxerre & 6 & 12 & 11 & 18 & 13 & 3 & 17 & & & \\
\hline AS Monaco & 17 & 17 & 18 & 18 & 18 & 17 & & & 13 & 12 \\
\hline AS Nancy Lorraine & 3 & 6 & 1 & 11 & 18 & 12 & 12 & 18 & & \\
\hline AS Saint-Etienne & 3 & 6 & 3 & 11 & 17 & 6 & 12 & 6 & 7 & 9 \\
\hline Evian TG FC & & & & & & & 10 & 18 & 9 & 9 \\
\hline FC Girondins de Bordeaux & 7 & 3 & 3 & 1 & 6 & 17 & 18 & 18 & 18 & 18 \\
\hline FC Lorient & & 3 & 9 & 15 & 3 & 3 & 5 & 6 & 12 & 18 \\
\hline FC Nantes & 18 & 17 & & 17 & & & & & 3 & 3 \\
\hline FC Sochaux Montbéliard & 2 & 3 & 18 & 12 & 6 & 1 & 6 & 12 & 18 & \\
\hline Le Mans UC 72 & 6 & 3 & 9 & 12 & 18 & & & & & \\
\hline LOSC Lille Métropole & 1 & 5 & 5 & 12 & 12 & 13 & 6 & 12 & 18 & 6 \\
\hline Montpellier Hérault SC & & & & & 1 & 6 & 1 & 5 & 17 & 6 \\
\hline OGC Nice & 3 & 1 & 5 & 6 & 15 & 8 & 18 & 1 & 17 & 12 \\
\hline Olympique de Marseille & 12 & 1 & 1 & 3 & 7 & 15 & 17 & 15 & 18 & 18 \\
\hline Olympique Lyonnais & 3 & 3 & 1 & 8 & 15 & 15 & 18 & 17 & 18 & 13 \\
\hline Paris Saint-Germain & 17 & 17 & 17 & 10 & 17 & 18 & 7 & 9 & 9 & 9 \\
\hline Racing Club de Lens & 12 & 6 & 5 & & 18 & 5 & & & & 18 \\
\hline SM Caen & & & 9 & 9 & & 18 & 12 & & & 9 \\
\hline Stade Rennais FC & 3 & 1 & 3 & 9 & 18 & 3 & 18 & 12 & 18 & 15 \\
\hline Toulouse FC & 12 & 7 & 11 & 7 & 12 & 12 & 12 & 6 & 6 & 17 \\
\hline Valenciennes FC & & 18 & 9 & 12 & 15 & 15 & 18 & 12 & 17 & \\
\hline
\end{tabular}




\section{Results}

The financial analysis sheds light on the heterogeneity of organizational aims among Ligue 1 clubs which could be the consequences of the uncertainty of the sports industry and/or of the diversity of the owners' preferences in the trade-off between win and profit maximization. To further understand the situation, 144 transitions between $t$ and $t+1$ are analyzed in Ligue 1 . For $67.3 \%$ of them (97 occurrences), the intended strategy is realized. Even where the sporting outcome remains unpredictable, for the most part French football clubs are able to achieve their desired orientation between win and profit. In 23 cases (16.0\% of the transitions) the strategic intent is not realized because the level of performance is significantly different from what was expected. Moreover, a swing from one orientation to another which could not be anticipated from the theoretical model is recorded for 24 transitions (16.7\%). ${ }^{[i i]}$ Over these 24 transitions, only two can be explained by a change in governance and/or ownership:

- Lorient switched from a soft budget constraint to one predicated on more rigorous financial management (15 to 3, see Table 7 ) with the arrival of a new majority shareholder between 2008/09 and 2009/10;

- The change of Chairman could explain the slackening of the budget constraint for Nice between 2008/09 and 2009/10 (6 to 15 , see Table 7).

This means that a new strategic intent was defined in $t+1$ for the 22 remaining transitions, adjusting the trade-off between win and profit in order to achieve a better alignment between the club and its environment. For clarification, several examples are described to highlight the three configurations. These figures provide an illustration of evolution viz a viz the multiple objectives of professional sports teams.

\section{Montpellier Hérault SC}

First, Montpelier Hérault SC was promoted to Ligue 1 from season 2009/10. From this season until season 2012/13, the club owner's objectives were oriented toward profit (although notably this did not prevent the club from achieving sporting success at the same time, being crowned champions in season 2011/12) as suggested by the descriptive analysis provided in Table 3 and Figure 2. Over this period, the strategic intent of the team was realized. However, the relative operating profit changed towards win maximization under a soft budget constraint in season 2013/14, before reverting to the initial objective the following season. The theoretical model classifies the first switch as an involuntary deviation from the organizational aim. The slackening of the budget constraint is explained by a non-maximal pure managerial efficiency, a negative productivity shock and a negative demand shock (typology 17). The unexpected poor performance during that season had implied a reduction in revenues (percentage variance of $49.4 \%$ from season 2012/13 to season 2013/14). Recovery of the performance in 2014/15 allowed Montpelier Hérault SC to realize a positive return again: relative operating profit increased from $-8.3 \%$ to $9.3 \%$. 


\section{Montpellier Hérault SC}

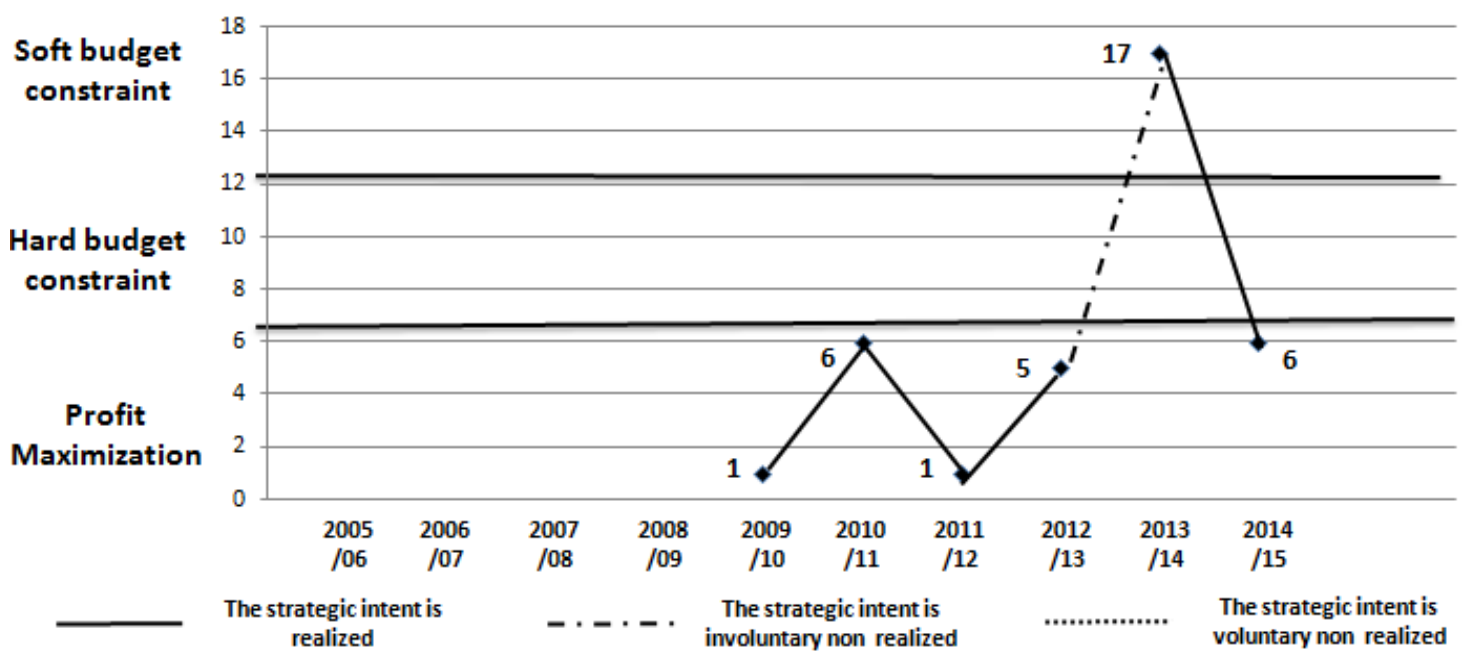

Figure 2 - The strategic evolution of Montpellier Hérault SC

\section{AC Ajaccio}

AC Ajaccio provides an example of a professional sport club which was able to adapt its strategy quickly to take advantage of new opportunities. The club was promoted to Ligue 1 from season 2011/12 after five seasons in the second division. Its return to the highest level was accompanied by a high probability of relegation as AC Ajaccio had the lowest payroll in the league. However, its perfect efficiency allowed the organization to avoid relegation. The typology observed (3) implies that its strategic intent can be orientated toward profit or win under hard budget constraint. However, its relative operating profits for the following two seasons are below the threshold of $-5 \%$, despite perfect efficiency and the absence of a productivity or demand shock (15). The only way to understand the slackening of the budget constraint is to assume that its strategic intent changed. During the first of its three successive seasons in Ligue 1, it seems that AC Ajaccio wanted to benefit from the new revenues offered through its promotion ${ }^{[i v]}$, while at the same time not adopting a strategy that was too risky in terms of retaining its first division status. However, in seasons 2012/13 and 2013/14, AC Ajaccio took the view that financial losses may be necessary to try and ensure the club had stability within Ligue 1 . This new trade-off between win and profit allowed AC Ajaccio to significantly increase its payroll: the percentage variance of this expenditure item between the first and the second seasons in Ligue 1 was $29.3 \%$. The club owner may have anticipated that temporary losses would provide a stable competitive foundation for AC Ajaccio in Ligue 1. 


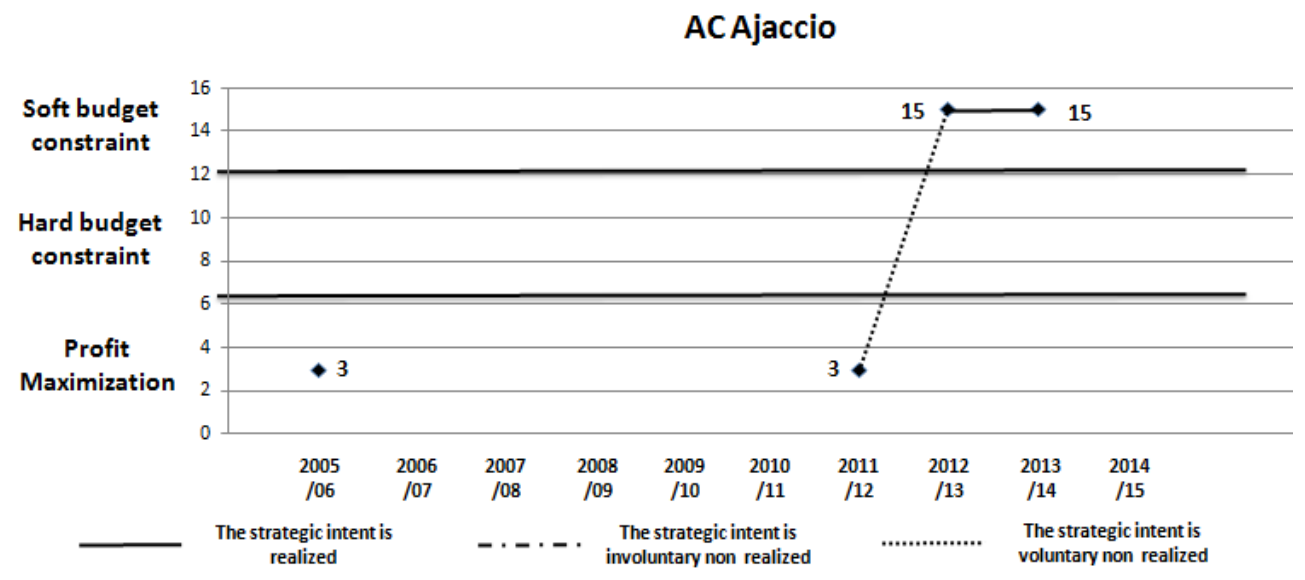

Figure 3 - The strategic evolution of AC Ajaccio

Adopting a soft budget constraint is, however, a risky strategy and one which did not pay off for AC Ajaccio. At the end of season 2013/14, the club was relegated and now suffers from significant financial difficulties. Indeed, in order to be able to recruit during the 2015/16 season winter transfer window, AC Ajaccio was forced to call upon its supporters for participatory financing. ${ }^{[v]}$

\section{LOSC Lille Métropole}

The strategic flexibility of LOSC Lille Métropole provides a good example of the benefits of modifying the weight of the trade-off between win and profit dependent upon environmental opportunities (Figure 4). In season 2009/10, LOSC Lille Métropole adopted a win maximization strategy under a hard budget constraint (typology 12). In the following season, the club increased its efficiency and benefited from a positive productivity shock. While this performance improvement might be expected to increase the club's relative operating profit, in fact the financial ratio decreased significantly (from $-0.2 \%$ to $-11.3 \%$ ). The only way to understand this diminution is to presume that LOSC Lille Métropole redefined its objectives. Two elements may explain the need to adapt its strategy for season 2010/11. First, the environment provided a major opportunity: after the Olympique Lyonnais (seven titles in a row from 2001/02 to 2007/08) and before the Paris SaintGermain (champions from 2012/13 to 2015/16) dynasties, there was room for other clubs to win Ligue 1. Second, LOSC Lille Métropole benefited from a 'golden generation' of players, personified by Eden Hazard. In order to be able to retain its best players for an additional year, the club owner permitted a softening of the budget constraint to fund a pay rise. . $^{[v]]}$ The percentage variance in the payroll between those two seasons was $15.6 \%$. This new trade-off between win maximization and profit maximization allowed LOSC Lille Métropole to become champions for the first time since 1954 .

While this strategic flexibility was timely in terms of sporting performance, it has had a profound impact on the club's financial situation. The percentage variance of the net equity was $-24.2 \%$ between seasons 2009/10 and 2010/11. In order to stabilize its finances, the following season heralded a new strategy. While its efficiency score is now non maximal, and there is no longer any shock (typology 6), its relative operating profit has increased significantly (from $-11.3 \%$ to $6.4 \%$ ) thanks to the transfer of players and additional revenues generated through its participation in the Champions League. The profit maximization orientation during season 2011/12 allowed LOSC Lille Métropole to reconstitute its net equity (percentage variance of $+24.2 \%$ ). The inter-temporal budget constraint of LOSC Lille Métropole has enabled the club to maximize its utility by modifying the 
trade-off between win and profit over the period 2009/10 to 2011/12 according to the opportunities in the environment.

\section{LOSC Lille Métropole}

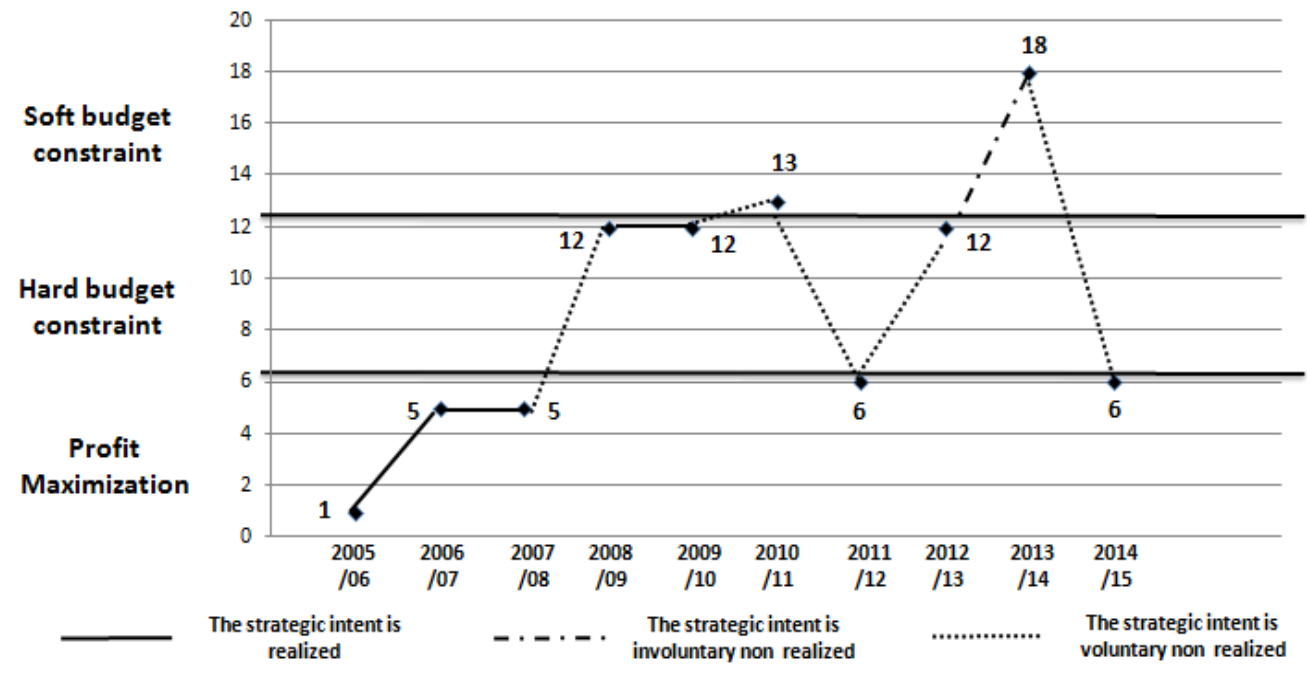

Figure 4 - The strategic evolution of LOSC Lille Métropole

\section{Discussion}

The typology based upon a dialectic analysis of the relation between the ends achieved and means used (Avenier, 1999) enables us to define the degree of compliance with a club's intended strategy. As a result it is possible to explain the determinants of the recurring deficits in the football industry. Thereafter, the implications of heterogeneity in club owners' behaviors in respect of the regulatory tools used by professional sports leagues will be discussed.

\section{Persistent losses: negative shocks, moral hazard or strategic intent?}

There is an abundant literature concerned with the relationship between ownership structure and organizational performance in economics and management in general, and for professional sport teams in particular (e.g. Leach and Szymanski, 2015; Wilson et al., 2013). In sports economics, the financial performance of clubs that acquired stock exchange listings is also thoroughly discussed. However, no statistical analysis is available for French listed clubs given that only two are listed (Olympique Lyonnais and Istres), these clubs going public in 2007. However, the theoretical model enables us to observe any shift toward profit maximization for Olympique Lyonnais (Istres was in Ligue 1 in 2004/05 only, so prior to the period studied).

Two distinct periods can be observed for Olympique Lyonnais (Figure 5). From 2005/06 to 2007/08, the utility function could correspond to either profit maximization or win maximization under a hard budget constraint. The derived typologies do not enable us to be certain about the orientation of Olympique Lyonnais. However, the shift toward win maximization under a soft budget constraint since season 2009/10 is clear. The prior season marked the end of the Olympique Lyonnais dynasty, with the club finishing third in Ligue 1 . Seeking to regain its position, Olympique Lyonnais softened its budget constraint to increase its payroll (percentage variance of $17.4 \%$ ) and to recruit new players (12 arrivals during the $2009 / 10$ season summer window transfer). If any shift was observed since the club's floatation, it reflected a lower weighting of the financial output. 


\section{Olympique Lyonnais}

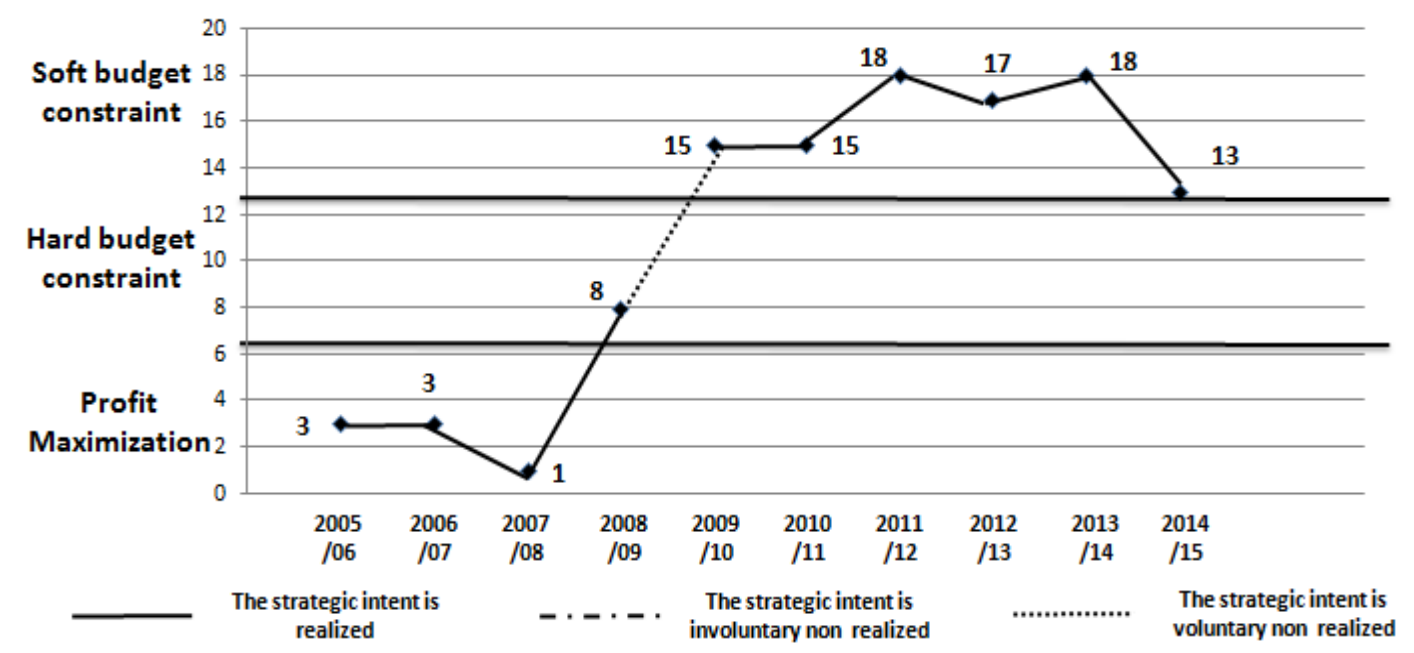

Figure 5 - The strategic evolution of Olympique Lyonnais

Beyond the ownership structure discussion, several alternative explanations are provided within the sports economics literature to understand recurring deficits in this industry. Szymanski (2012) provides two such explanations. First, that the irrational exuberance of club owners may encourage them to invest more than they can afford in talent in order to achieve a better sporting performance. A desire to curtail this type of behaviour was one driver in the Union of European Football Associations' (UEFA) introduction of Financial Fair-Play regulations (UEFA, 2012). However, the analysis of the insolvency in English (Szymanski, 2012) and French (Scelles, Szymanski and DermitRichard, 2016) football suggest that it is negative productivity and/or demand shocks which explain the financial collapse of professional teams rather than the behaviour of club owners, with insolvency being "caused by consistent underperformance relative to expectations" (Szymanski, 2012, p. 16).

The concept of soft budget constraint provides a middle way between those two alternative explanations. Whereas the idea of negative shocks relies on involuntary losses, the first concept assumes that they can be deliberate, while being rational since deficits result from the agency relationship between the club's director and the other stakeholders.

Table 2 identifies 68 clubs with a relative operating profit below $-5 \%$. For 55 of these clubs, it was possible to measure the degree of compliance with the intended strategy. $32.7 \%$ of the observations (18 occurrences) reflect an unrealized strategy: the result of a productivity and/or demand shock and the inefficiency of those organizations explain their losses. This suggests that most of the time (the remaining 37 cases, $67.3 \%$ ) the operating deficit is intentional.

According to the soft budget constraint, this orientation toward win maximization could be chosen by the club's director to the detriment of other stakeholders. Therefore, it appears necessary to control for an agency relationship issue that characterizes the concept of a soft budget constraint in the remaining 37 transitions. As the shareholders are most frequent last funders of last resort in Ligue 1 (Andreff, 2007; DNCG, 2015), the possibility of a moral hazard between the director and the main shareholders is assessed. This analysis does not enable us to ascertain the existence of a moral hazard when the director is not the main shareholder. In 20 observations, the intended orientation 
toward win maximization under soft budget constraint could be explained by the opportunistic behavior of the club director as he does not have to pay the burden. However, in the 17 remaining observations, the main shareholder is also the club director. This implies that the intention to prioritize wins at the expense of the financial objective has been accepted by the main shareholder in those organizations. It seems that the persistent losses are commonly explained by an intended strategy, agreed by the main shareholder, to maximize win under soft budget constraint.

\section{Win or profit maximization? Win and profit maximization? The implications for policy regulation}

Many regulatory tools could be used in professional leagues, their objectives being concerned with, for example, the need to protect the competitive balance of the league (i.e. the uncertainty of outcome) and/or clubs' solvency. According to the invariance principle (Rottenberg, 1956; Szymanski and Késenne, 2004), the efficiency of those regulatory tools depends on the club owners' utility function. If the club favours wins at the expense of profit, then they will have an effect on the equilibrium of the league.

The heterogeneity of behaviours observed in Ligue 1 - both between clubs within the league and for a given team according to the season analyzed - challenges the results of the previous research studies based on the basic premise that European leagues are more oriented toward wins. The assumption, focusing on the trade-off between win and profit maximization, does not seem accurate, which inevitably has implications for policy interventions. The additive utility function formalized by Rascher (1997) could enable heterogeneity to be introduced thanks to its parameter $\alpha_{i}$ which gives the proportion that the owner $i$ trades off between winning and profit. However, this parameter should also include a temporal dimension to reflect the possibility of a club's owner changing his/her preferences according to environmental opportunities. The parameter should also allow the owner to maximize wins under a soft budget constraint. Terrien et al. (2016a) provide an analytical treatment of a league with one team oriented toward wins under a hard budget constraint while the other does not look for the break-even position. This assumption results in a reversal of the argument over the effectiveness of the regulatory tools. This remark echoes Fort (2015)'s plea for a better assessment of the weight between win and profit in order to obtain a better idea of the implications of regulatory tools.

Such tools are also used to promote financial sustainability among professional sport teams. In its trans-European football competitions, UEFA has introduced Financial Fair Play (FFP) regulations, central to which is a requirement for clubs to break even in terms of their footballing income and expenditure (for more details, see Wilson et al., 2013 and Morrow, 2014b) and to put an end to the "irrational exuberance" evidence in the behaviour of some club owners (Szymanski, 2012). Failing to comply with FFP may lead to sanctions including financial penalties and the exclusion of a club from European competitions (Morrow, 2014b). As European competitions, particularly the UEFA Champions' League are very lucrative [vii], paradoxically either of these two sanctions could exacerbate the consequences of a negative shock which induced the deficit in the first instance; this within a regulatory system designed to minimize such deficits. On the other hand, FFP may also "restores incentives for 'good management" (Franck, 2014, p. 197) and therefore limits the occurrence of the negative productivity and/or demand shocks. 
Even if the findings show that financial losses could be intentional, it does not mean that this automatically irrational. Using the resource-based view, Mauws, Mason and Forster (2003) explain why it is strategically interesting to own a professional sport team even if its profitability is diminishing. Moreover, losses could be part of an inter-temporal budget constraint, temporary unprofitability being accepted allows the club to pursue a particular strategy. For example, LOSC Lille Métropole benefited from this flexible trade-off, specifically increasing its revenues in the following season thanks in particular to its participation in the UEFA Champions' League. By preventing strategic flexibility, there is a risk that Financial Fair Play will create less competition and strengthen the competitive position of the existing hierarchy of top clubs (Sass, 2016).

The results of season 2014/15 provide an example of such a risk. Upon its return to Ligue 1 during season 2013/14, AS Monaco adopted a win maximization strategy under a very soft budget constraint. Despite perfect efficiency, a positive productivity shock and a positive demand shock (typology 13 ), its relative operating profit was $-65.6 \%$. This orientation allowed the club to recruit very good players (such as James Rodriguez, Radamel Falcao and Anthony Martial) and to become a serious challenger to Paris Saint-Germain. The trade-off between win and profit reduced the competitive imbalance of the league, at least in terms of the title - Paris Saint-Germain only gained 9 points more than AS Monaco, which in turn broke the record for the number of points won by the second placed team in Ligue 1.

The following season, however, AS Monaco adapted its strategy to satisfy the requirements of UEFA Financial Fair Play. ${ }^{[v i i i]}$ Despite the inefficiency of the team and the negative demand shock (due to the reduction of shareholder investment), the financial situation was redressed, with a relative operating profit equal to $4.2 \%$. This recovery was possible thanks to additional revenues gained from participation in the Champions' League, a decrease in payroll (the percentage variance in payroll fell by $10.9 \%$ ), and player sales (e.g. Jaime Rodriguez) and/or player loans (e.g. Radamel Falcao). This new strategy can be explained, in part at least, by the requirement to comply with UEFA Financial Fair Play ${ }^{[i x]}$ This adaptation of the strategic intent could be related to the imposed strategy described by Mintzberg and Waters (1985, p. 268). During season 2014/15, the gap between AS Monaco and Paris Saint-Germain increased (12 points) while Paris Saint-Germain lost 6 points compared to the prior season. Ultimately the uncertainty of outcome viz a viz the title was maintained thanks to Olympique Lyonnais over performing in that season (maximal efficiency and positive productivity shock), with Paris Saint-Germain only gaining 8 points more than Olympique Lyonnais and AS Monaco finishing in third place. Nevertheless, the lower contention for the title in Ligue 1 - arising in part from responses to the introduction of FFP - was evident during season 2015/16 with a 31 points differential between Paris Saint-Germain and the second and third-ranked teams (Olympique Lyonnais and AS Monaco again).

\section{Conclusion}

The paper confirms empirically that there is not a single weighting between profit and win objectives within a professional sport league. During a given year, some clubs maximizing profit under sporting constraint face teams that recruit more talent than would be possible in complying with a break-even position. Moreover, these organizations can switch from one orientation to another in order to seize the opportunities offered within their environment and hence to maximize their utility. The findings 
from this study enable an improved understanding and characterization of the trade-off between wins and profit, even if these are not specifically measured in this study. For example LOSC Lille Métropole highlights how a flexible trade-off between win and profit enabled that club to be crowned champions without threatening its financial sustainability, but at the same time the case of Ajaccio emphasizes the risk associated with that strategy which should be implemented only if a club has the means of achieving the new strategic segment. ${ }^{[x]}$

The paper confirms Rascher's (1997) assumption that the weights in the trade-off between profit and win can change between two clubs competing in the same league. By adding a temporal parameter to this weighting, the paper goes further to offer an enhanced understanding of the impact of policy regulation in professional sports leagues (Fort, 2015). Whereas the invariance principle should not apply to European football leagues where clubs are assumed to adopt a win maximization strategy, the findings lead us to question the relevance of the actual regulatory tools used in professional leagues.

The results are also interesting in terms of seeking to reconcile competing theories dealing with persistent losses in the football industry. The random nature of sporting competition could explain part of the deficits observed (Szymanski, 2012), while the other part could be intentional (Andreff, 2007; Storm and Nielsen, 2012) and accepted by the shareholders. To enhance the understanding of the financial difficulties facing football clubs it is necessary to adopt the optimal regulatory tools to ensure the sustainability of this industry.

However, as the results are not generalizable outside of the French Ligue 1, further research based on other football leagues is required to extend the findings of this paper. Nevertheless, the result provides quantitative confirmation of the results of the case study undertaken by Carlsson-Wall, Krauss and Messner (2016, pp. 55-56), in which a Swedish football club deviated from its break-even requirement according to the sporting aim (risk of relegation or title opportunity).

Moreover, there remains a need for additional research around the trade-off between the multiple objectives of professional sport teams but which is not limited to the debate between profit and win maximization, for example, including objectives related to social, community and corporate social responsibility activities (Anagnostopoulos and Kolyperas, 2015; Bason and Anagnostopoulos, 2015; Breitbarth et al., 2015) and of how to accurately estimate the weighting of these multi-faceted objectives.

\section{References}

Anagnostopoulos, C. and Kolyperas, D. (2015), "Corporate social responsibility of and through sport", in Byers, T. and Gorse, S. (Eds.), Introduction to Sport Management: A Contemporary Issues Perspective, Sage Publications, London, pp. 473-486.

Andreff, W. (2007), "French Football A Financial Crisis Rooted in Weak Governance", Journal of Sports Economics, Vol.8 No.6, pp. 652-661.

Andreff, W. (2014), "La performance financière des organisations sportives à but non lucratif : quels enjeux, quels outils ?", in Winand, M. \& Zintz, T. (Ed.). Management et évaluation de la performance: Un défi pour les organisations sportives. Management \& Sport, De Boeck, Louvain-La-Neuve. 
Andreff, W. (2016), "Financing structures in not-for profit sport clubs and professional teams", Paper presented at the Oman Annual Sport Congress, Muscat, April 18.

Ascari, G., and Gagnepain, P. (2006), "Spanish football", Journal of Sports Economics, Vol. 7 No. 1, pp. 76-89.

Avenier, M. J. (1999), "La complexité appelle une stratégie chemin faisant", Gestion 2000, pp. 13-34.

Baroncelli, A., and Lago, U. (2006), "Italian football", Journal of Sports Economics, Vol. 7 No. 1, pp. 1328.

Barros, C. P., and Garcia-del-Barrio, P. (2011), "Productivity drivers and market dynamics in the Spanish first division football league", Journal of Productivity Analysis, Vol. 35 No. 1, pp. 5-13.

Bason, T. and Anagnostopoulos, C. (2015), "Corporate social responsibility through sport: A longitudinal study of the FTSE100 companies", Sport, Business and Management: An International Journal, Vol. 5 No. 3, pp. 218-241.

Breitbarth, T., Walzel, S., Anagnostopoulos, C. and van Eekeren, F. (2015), "Corporate social responsibility and governance in sport", Corporate Governance: The International Journal of Business in Society, Vol. 15 No. 2, pp. 254-273.

DNCG. (2015). Situation du football professionnel. Saison 2013/2014.

Fort, R. (2015), "Managerial objectives: A retrospective on utility maximization in pro team sports", Scottish Journal of Political Economy, Vol. 62 No. 1, pp. 75-89.

Franck, E. (2014), "Financial Fair Play in European Club Football -What is it all about?", International Journal of Sport Finance, Vol. 9 No 1, pp. 193-217.

Franck, E. (2015), "Regulation in leagues with clubs' soft budget constraints: the effect of the new UEFA Club Licensing and Financial Fair Play Regulations on managerial incentives and suspense", in: Andreff, W. (Ed.), Disequilibrium Sports Economics: Competitive Imbalance and Budget Constraints, Cheltenham,pp. 228-249.

Guzmán, I., and Morrow, S. (2007), "Measuring efficiency and productivity in professional football teams: evidence from the English Premier League", Central European Journal of Operations Research, Vol. 15 No. 4, pp. 309-328.

Hall, S., Szymanski, S., \& Zimbalist, A. S. (2002), "Testing causality between team performance and payroll the cases of major league baseball and English soccer", Journal of Sports Economics, Vol. 3 No. 2, pp. 149-168.

Kern, A., Schwarzmann, M., and Wiedenegger, A. (2012), "Measuring the efficiency of English Premier League football: A two-stage data envelopment analysis approach", Sport, Business and Management: An International Journal, Vol. 2 No. 3, pp. 177-195.

Késenne, S. (1996), "League management in professional team sports with win maximizing clubs", European Journal for Sport Management, Vol. 2 No. 2, pp. 14-22. 
Kornaï, J. (1980), "Economics of shortage: Volumes $A$ and B", The Netherlands: North Holland, Amsterdam.

Lassalle, F., Meschi, P. X., and Métais, E. (2012), "L'écart entre performance et aspirations affecte-t-il la performance future d'une organisation? Le cas de la Ligue des Champions UEFA (1994-2008) ", Finance Contrôle Stratégie, Vol. 15 No. 4, pp. 71-87.

Leach, S. A. (2007), "Financial viability and competitive balance in English football", PhD dissertation, Imperial College London.

Leach, S., and Szymanski, S. (2015), "Making money out of football", Scottish Journal of Political Economy, Vol. 62 No. 1, pp. 25-50.

Madden, P., and Robinson, T. (2012), "Supporter influence on club governance in a sports league: A "utility maximization" model", Scottish Journal of Political Economy, Vol. 59 No. 4, pp. 339-360.

Mauws, M. K., Mason, D. S., and Foster, W. M. (2003), "Thinking strategically about professional sports", European Sport Management Quarterly, Vol. 3 No. 3, pp. 145-164.

Mintzberg, H., Ahlstrand, B., and Lampel, J. (1998), "Strategy safari: A guided tour through the wilds of strategic management", Free Press, New York.

Mintzberg, H., and Waters, J. A. (1985), "Of strategies, deliberate, and emergent", Strategic Management Journal, Vol. 6 No. 3, pp. 257-272.

Morrow, S. (2014a), "Football finances", In J. Goddard and P. Sloane (eds.), Handbook on the Economics of Professional Football. Edward Elgar: Cheltenham, pp. 80-99.

Morrow, S. (2014b), "Financial Fair Play - Implications for Financial Reporting (ICAS Research Monograph)", The Institute of Chartered Accountants of Scotland: Edinburgh.

Plumley, D., Wilson, R., and Ramchandani, G. (2014), "Towards a model for measuring holistic performance of professional Football clubs", Soccer \& Society, (ahead of print), pp. 1-14.

Quirk, J. and El Hodiri, M. (1974), "The economic theory of a professional sports league. In R. G. Noll (ed.), Government and the Sports Business", The Brookings Institution: Washington, DC, pp. 33-80.

Rascher, D. A. (1997), "A model of a professional sports league", In W. Hendricks (ed.), Advances in the Economics of Sport, Vol. 2. CT: JAI Press Inc: Greenwich, pp. 27-76.

Rottenberg, S. (1956), "The baseball players' labor market", The Journal of Political Economy, Vol. 64, pp. 242-258.

Sass, M. (2016), "Glory hunters, sugar daddies, and long-term competitive balance under UEFA financial fair play”, Journal of Sports Economics, Vol. 17, pp. 148-158.

Scelles, N., Szymanski, S., \& Dermit-Richard, N. (2016), "Insolvency in French soccer: The case of payment failure", Journal of Sports Economics, OnlineFirst, doi:10.1177/1527002516674510

Sloane, P. (1971), "The economics of professional football: the football club as a utility maximizer", Scottish Journal of Political Economy, Vol. 18 No. 2, pp. 121-146. 
Sloane, P. J. (2015), "The economics of professional football revisited", Scottish Journal of Political Economy, Vol. 62 No. 1, pp. 1-7.

Storm, R. K. (2012), "The need for regulating professional soccer in Europe: A soft budget constraint approach argument", Sport, Business and Management: An International Journal, Vol. 2 No. 1, pp. 21-38.

Storm, R. K., and Nielsen, K. (2012), "Soft budget constraints in professional football", European Sport Management Quarterly, Vol. 12 No. 2, pp. 183-201.

Szymanski, S. (2012), "Insolvency in English professional football: Irrational exuberance or negative shocks?", Working Paper. Retrieved from http://www.soccernomicsagency.com/wordpress/wpcontent/uploads/2012/11/Insolvency-and-English-football.pdf

Szymanski, S., and Késenne, S. (2004), "Competitive balance and gate revenue sharing in team sports", The Journal of Industrial Economics, Vol. 52 No. 1, pp. 165-177.

Szymanski, S. and Zimbalist, A. (2005), "National Pastime; How Americans Play Baseball and the Rest of the World Plays Soccer", Brookings Institution Press: Washington DC.

Terrien, M., Scelles, N., and Durand, C. (2016), "French 75\% Tax Rate: An opportunity to optimize the attractiveness of the French soccer league", International Journal of Sport Finance, Vol. 11 No. 3, pp. 183-203.

UEFA. (2011). The European club licensing benchmarking report: Financial year 2011. Retrieved from http://www.uefa.org/MultimediaFiles/Download/Tech/uefaorg/General/01/91/61/84/1916184 DO WNLOAD.pdf

UEFA (2012). Financial Fair Play Regulations. Retrieved from http://www.uefa.com/MultimediaFiles/Download/Tech/uefaorg/General/01/80/54/10/1805410 DO WNLOAD.pdf

Vrooman, J. (1997), "A unified theory of capital and labor markets in major league baseball", Southern Economic Journal, Vol. 63 No. 3, pp. 594-619.

Wilson, R., Plumley, D., and Ramchandani, G. (2013), "The relationship between ownership structure and club performance in the English Premier League", Sport, Business and Management: An International Journal, Vol. 3 No. 1, pp. 19-36.

\footnotetext{
${ }^{i}$ All the reports are available here: http://www.lfp.fr/corporate/dncg

ii 'Positive' (or 'Negative') means positive (negative) productivity (or demand) shock and also positive (negative) or no demand (or productivity) shock. 'No' means neither productivity nor demand shock or opposite effect.

iii Seven indirect transitions between $t$ and $t+\Delta t$ (with $\Delta t>1$ ) also reflect a strategic realignment of the organization.

iv The coefficient of the promotion dummies is significantly positive in the demand function (Table 5). To provide an idea of the difference in revenues between Ligue 1 and Ligue 2, the worst team of the first division (RC Lens) obtained $€ 13.5 \mathrm{M}$ from the TV rights in 2014/15, while the best club in Ligue 2 (ESTAC Troyes) only received €5.2M.

$\checkmark \quad$ http://sport24.lefigaro.fr/le-scan-sport/business/2015/12/16/27004-20151216ARTFIG00189-ajaccio-lanceun-appel-aux-dons-des-supporteurs-pour-recruter.php
} 
vi The contracts of Eden Hazard, Aurélien Chedjou, Florent Balmont... were renegotiated. See https://fr.wikipedia.org/wiki/Saison_2010-2011_du_LOSC_Lille_M\%C3\%A9tropole

vii The 2015 DNCG Report notices that the participation in the Champions League allows French football teams to generate between 30 and $60 \mathrm{M} €$ of additional revenues.

viii Despite its new strategic orientation, Monaco was sanctioned and had to pay a penalty of $€ 13 \mathrm{M}$ : http://www.lemonde.fr/football/article/2015/05/08/fair-play-financier-dix-clubs-dont-monaco-acceptent-lessanctions-de-I-uefa_4630487_1616938.html

ix http://www.footmercato.net/ligue1/fair-play-financier-vasilyev-justifie-la-strategie-de-monaco-et-ne-veutpas-entendre-parler-d_139307

${ }^{x}$ Despite the softening of the budget constraint, AC Ajaccio still had the lowest payroll in Ligue1 during the season 2013/14, making difficult to ensure the club had stability in Ligue 1 to overcome those temporary losses. 